A N N A LES

UNIVERSITATIS MARIAE CURIE-SKŁODOWSKA LUBLIN - POLONIA

VOL. LXXI, z. 2

SECTIO B

2016

Instytut Geografii, Uniwersytet Pedagogiczny im. KEN w Krakowie

30-084 Kraków, ul. Podchorążych 2

damian.heldak@gmail.com

\title{
DAMIAN HEŁDAK
}

\section{Rozwój usług turystycznych na Podhalu na przykładzie miejscowości Białka Tatrzańska}

Development of tourist services in Podhale as exemplified by the village Białka Tatrzańska

Słowa kluczowe: Białka Tatrzańska, turystyka narciarska, turystyka SPA \& Wellness, agroturystyka, turystyka biznesowa tourism

Keywords: Białka Tatrzańska, ski tourism, SPA \& Wellness tourism, agrotourism, business

\section{WPROWADZENIE}

W XXI wieku coraz bardziej rozwijają się usługi turystyczne. Związane jest to zarówno z rozwojem infrastruktury turystycznej, jak i coraz większym zapotrzebowaniem na ten rodzaj usług (Kaczmarska 2014). Widoczne jest to także na Podhalu, gdzie od kilkunastu lat rozwija się przede wszystkim turystyka kwalifikowana, zwłaszcza narciarska. Celem niniejszej pracy jest przedstawienie historii rozwoju różnych form turystyki na Podhalu na przykładzie miejscowości Białka Tatrzańska, począwszy od agroturystyki, którą rozumie się jako rodzaj turystyki na terenach wiejskich, związanej z działalnością gospodarstwa rolnego, a uprawa roślin i chów zwierząt $\mathrm{w}$ takim gospodarstwie należy do jednych z głównych atrakcji (Leszka 2013), aż po turystykę SPA \& Wellness, w której głównym celem turysty jest „troska o urodę i tężyznę fizyczną” (Leszka 2013). Starano się określić kolejność pojawiania się określonych form turystyki w tej miejscowości, a jednocześnie wskazać na uwarunkowania ich rozwoju. W ten sposób wyznaczono kolejne etapy rozwoju usług turystycznych w Białce Tatrzańskiej. Aby zrealizować wyżej wymienione cele, posłużono się metaanalizą literatury przedmiotu 
oraz informacji zawartych w Internecie (zwłaszcza dotyczących oferty turystycznej). Przeprowadzono również rozmowy z lokalnym Stowarzyszeniem „Czas na Białkę" oraz przeanalizowano mapy tematyczne tego obszaru. W opracowaniu wykorzystano klasyfikację usług turystycznych dostępną w literaturze (Gaworecki 2003; Leszka 2013).

\section{CHARAKTERYSTYKA FIZYCZNOGEOGRAFICZNA MIEJSCOWOŚCI BIAŁKA TATRZAŃSKA}

Według regionalizacji fizycznogeograficznej Polski (Kondracki 2009) miejscowość Białka Tatrzańska znajduje się w mezoregionie Pogórze Spisko-Gubałowskie. Sama miejscowość leży na lewym brzegu rzeki Białki (ryc. 1), mającej swoje źródła w Tatrach. Koryto tej rzeki zbudowane jest głównie z różnej wielkości otoczaków granitowych, przytransportowanych przez rzekę z obszaru Krystalinika Tatr. Budowa geologiczna jest stosunkowo prosta - teren ten zbudowany jest z naprzemianlegle ułożonych warstw piaskowców i łupków, tworzących flisz podhalański (Mastella i in. 1996). W powierzchniowej warstwie podłoża występują ponadto wspomniane otoczaki granitowe, będące śladem m.in. zmian koryta Białki i jego lateralnego przesuwania się w kierunku wschodnim na niektórych odcinkach (Baumgart-Kotarba 1983). W dolinie Białki obecna jest strefa uskokowa, która w rzeźbie przejawia się występowaniem kilkudziesięciometrowych skarp, zwłaszcza na prawym brzegu rzeki w obrębie zachodnich stoków Czarnej Góry (Hełdak 2014). Ciekawe odsłonięcia geologiczne i rzeźba terenu sprzyjają rozwojowi geoturystyki na tym terenie.

Samo dno doliny jest łagodnie nachylone, co umożliwiło budowę drogi oraz rozwój zabudowy. W kierunku zachodnim wysokości bezwzględne jednak zaczynają stopniowo wzrastać i przekraczają nawet 900 m n.p.m. (np. Kotelnica Białczańska 918 m n.p.m.). Otwarcie doliny Białki w kierunku południowym gwarantuje dobre nasłonecznienie, a spore wysokości bezwzględne, o których już wspomniano, sprawiają, że średnia wysokość opadów atmosferycznych jest tu wyższa o około 200-300 mm od średniej dla Polski (http://krakow.rzgw.gov.pl/Program_Bialka/Opracowanie.pdf). Większa (około 130, przy średniej dla Polski około 56) jest również średnia liczba dni w roku z pokrywą śnieżną (http://klimat. imgw.pl/wp-content/uploads/2013/01/1_6.pdf), co ma niebagatelne znaczenie dla rozwoju turystyki narciarskiej.

Pod względem administracyjnym miejscowość należy do gminy Bukowina Tatrzańska w powiecie tatrzańskim (województwo małopolskie). Według Banku Danych Lokalnych w 2009 roku miejscowość zamieszkiwało 2157 osób. 


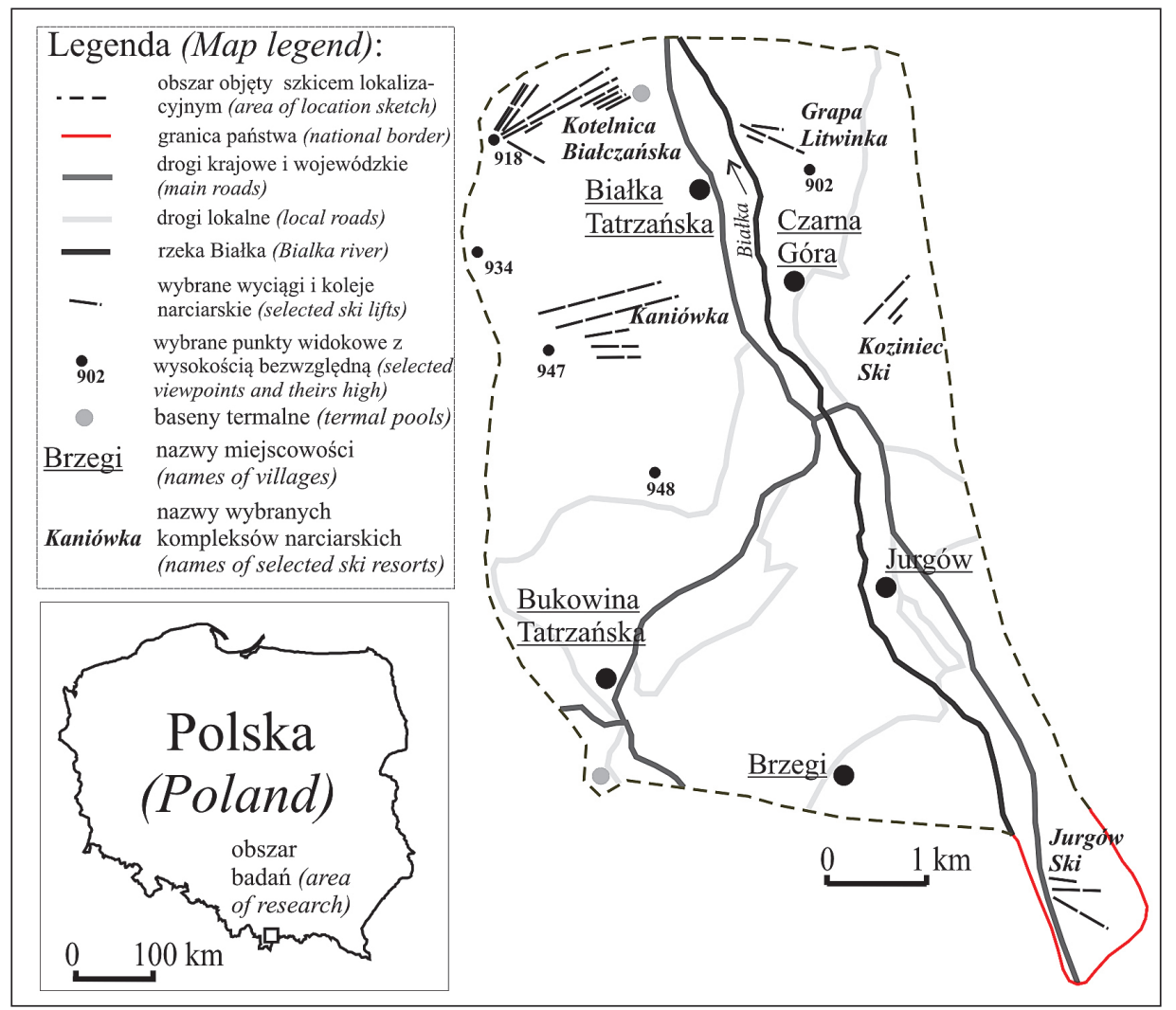

Ryc. 1. Lokalizacja Białki Tatrzańskiej i sąsiednich miejscowości na fragmencie szkicu gminy Bukowina Tatrzańska

Źródło: Opracowanie własne na podstawie mapy topograficznej Polski, arkusz 183.3 Zakopane Pn

Fig. 1. Location of Bialka Tatrzanska and neighboring villages on the fragment of the sketch of Bukowina Tatrzańska commune

Source: Own elaboration based on topographic map of Poland, sheet 183.3 Zakopane Pn

\section{POCZĄTKI TURYSTYKI W MIEJSCOWOŚCI BIAŁKA TATRZAŃSKA}

Atrakcyjny krajobraz, słabe zaludnienie i czyste środowisko zadecydowały o tym, że wraz z odzyskaniem przez Polskę niepodległości, najprawdopodobniej już w roku 1918 pojawili się tutaj pierwsi turyści (http://www.czasnabialke.pl/bialka_tatrzanska/historia). W tym okresie (1918-1939) można więc mówić o początkach turystyki tej miejscowości. W związku z tym, że polegała ona na przyjmowaniu turystów w prywatnych domach, gdzie podstawą utrzymania była najczęściej uprawa roli i chów zwierząt, możemy stwierdzić, że był to początek agroturystyki $\mathrm{w}$ tej miejscowości, pomimo że zjawisko to $\mathrm{w}$ literaturze przedmiotu nazwano i zaczęto powszechnie stosować dopiero od początku lat 90. 
ubiegłego stulecia (Uglis, Jęczmyk 2015). Oczywiście, miała ona niewielkie znaczenie gospodarcze, gdyż turyści pojawiali się tutaj sporadycznie. Ponadto, II wojna światowa zatrzymała, z pewnością powolny wtedy, rozwój agroturystyki na tym obszarze. Po wojnie ta forma turystyki po raz kolejny się rozwinęła i tak było aż do mniej więcej początku lat 90. XX wieku (http://www.czasnabialke.pl/ bialka_tatrzanska/historia). Obecnie, rozwój turystyki masowej, nastawionej na maksymalizację zysku, spowodował, że rozwój agroturystyki został zatrzymany - gospodarstwa agroturystyczne zastępowane są pensjonatami, domami wczasowymi, a nawet hotelami (ryc. 2). Obecnie w bazie noclegowej „tatry ski” znajduje się tylko jedno takie gospodarstwo. Można więc mówić o upadku tej formy turystyki w Białce Tatrzańskiej.

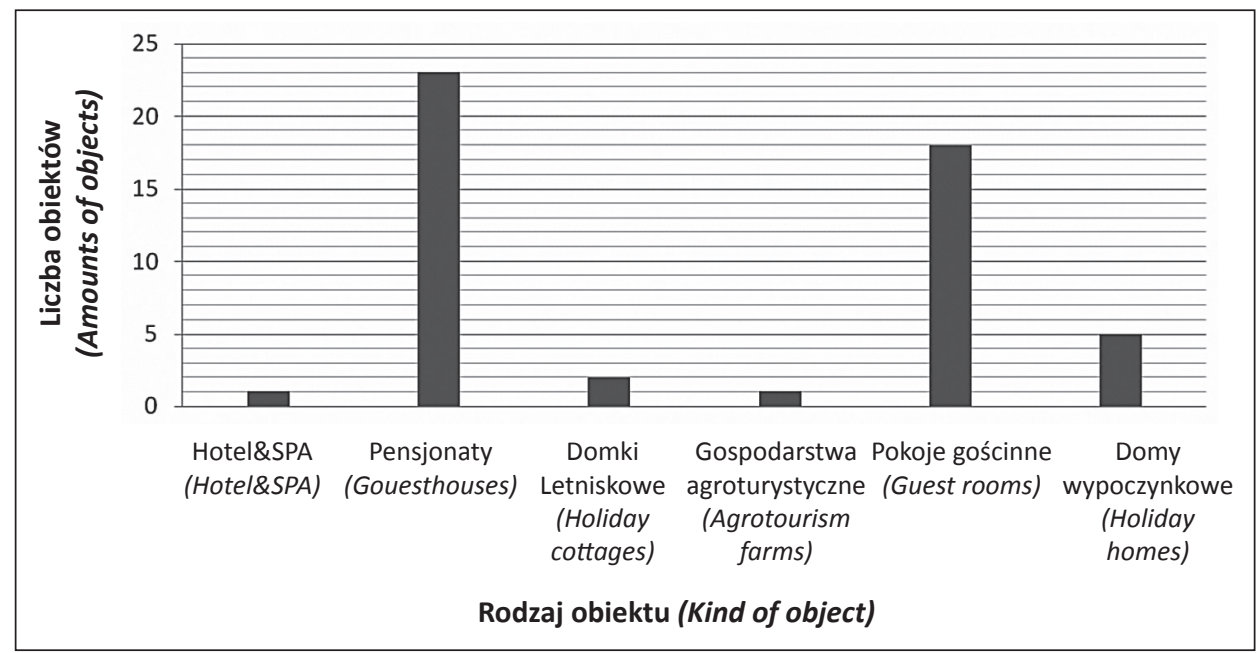

Ryc. 2. Aktualny stan bazy noclegowej w Białce Tatrzańskiej

Źródło: Opracowanie własne na podstawie bazy noclegowej w serwisie tatryski.pl [dostęp: 13.10.2015]

Fig. 2. Current state of accommodation in Biatka Tatrzańska

Source: Own elaboration based on accomodation facilities at tatryski.pl [access: 13.10.2015]

\section{ROZWÓJ TURYSTYKI PIESZEJ}

Wraz z rozwojem Polskiego Towarzystwa Turystyczno-Krajobrazowego, po 1950 roku na szerszą skalę zaczęto oznaczać szlaki turystyczne (Stasiak 2006). Właśnie w tym okresie najprawdopodobniej wyznakowano na terenie Białki Tatrzańskiej szlaki turystyczne (czerwony, zielony i żółty) istniejące do dzisiaj. Niestety, jak twierdzą członkowie Stowarzyszenia „Czas na Białkę”, szlaki te są słabo oznakowane i zdarza się, że turyści nieświadomie z nich zbaczają. Wydaje się, że w związku z tym turystyka piesza nie rozwija się najlepiej. Jest to jeden z tych 
sektorów turystyki w Białce Tatrzańskiej, który ma spory, ale niewykorzystany potencjał. Członkowie Stowarzyszenia „Czas na Białkę” zdają sobie z tego sprawę, gdyż dostrzegają potrzebę poprawy oznaczeń szlaków oraz budowy zadaszonych punktów postojowych.

Turystyka piesza, jeżeli jest już uprawiana w Białce Tatrzańskiej, to spełnia rolę uzupełniającą w stosunku do innych form turystyki, o których będzie mowa w dalszej części.

\section{ROZWÓJ TURYSTYKI KWALIFIKOWANEJ (NARCIARSKIEJ)}

Stoki o odpowiednim nachyleniu (np. Kotelnica Białczańska - ok. 19\%) oraz korzystne warunki klimatyczne, o których wcześniej wspomniano, sprawiły, że w Białce Tatrzańskiej w latach 70. XX wieku zrodził się pomysł wybudowania wyciągów narciarskich. Pierwszy z nich, który powstał w roku 1977, należał do Kopalni Węgla Kamiennego „Bolesław Śmiały” (http://www.bialka.tatrzanska. com). Obok niego, już rok później, zorganizowano pierwszy wyciąg orczykowy. Oba wyciągi zostały ulokowane na tzw. Bani, obok współczesnego kompleksu narciarskiego Kotelnica Białczańska.

Stopniowo powstające wyciągi spowodowały gwałtowny rozwój turystyki kwalifikowanej - narciarskiej. Szczególny rozwój kompleksów narciarskich zanotowano po roku 1989, a zwłaszcza od roku 1995. Współcześnie w Białce Tatrzańskiej funkcjonuje aż 8 kolei krzesełkowych (w sezonie zimowym 2015/2016 było ich już 9) i niemal 20 wyciągów orczykowych o różnym stopniu trudności. Dodatkową atrakcją dla narciarzy są trasy biegowe oraz tory snowtubingowe. Na uwagę zasługuje fakt, że praktycznie wszystkie stacje narciarskie wyposażone są w armatki śnieżne, co umożliwia sztuczne naśnieżanie tras. Standardem jest również regularne ratrakowanie stoków. W skład infrastruktury wchodzą także liczne punkty gastronomiczne. Celem tak rozbudowanej struktury ośrodków narciarskich jest świadczenie jak najbardziej kompleksowych usług.

\section{TURYSTYKA SPA \& WELLNESS}

Jedną z form, poszerzających zakres usług turystycznych, jest turystyka SPA \& Wellness, związana z wodami geotermalnymi obecnymi w podłożu fliszowym Podhala.

Pomysł budowy basenów termalnych zrodził się w tej miejscowości w roku 2005. Już rok później zawiązano spółkę z ograniczoną odpowiedzialnością prawną o nazwie Park Wodny Bania Spółka z o.o. i zaczęto wykonywać odwiert. Spółka uzyskała pozwolenie na odwiert do głębokości $2500 \mathrm{~m}$. Ostatecznie wodę 
geotermalną odwiercono na głębokości $2340 \mathrm{~m}$. W roku 2011 dokonano otwarcia kompleksu basenów termalnych o nazwie Terma Bania. Oprócz funkcji SPA \& Wellness baseny te są też formą relaksu (zjeżdżalnie, karuzele wodne) oraz sposobem mieszkańców Białki Tatrzańskiej na przyciągnięcie turystów także w sezonie letnim.

\section{TURYSTYKA BIZNESOWA}

W związku z wieloma możliwościami spędzenia czasu w Białce Tatrzańskiej rozwinęła się tutaj tzw. turystyka biznesowa (motywacyjna i konferencyjna). Przykładowo, do celów szkoleniowych i konferencyjnych oddano kilka sal konferencyjnych (ryc. 3), np. w Pensjonacie Toporów (otwartym w roku 1994). Największa z nich może pomieścić ponad 200 osób.

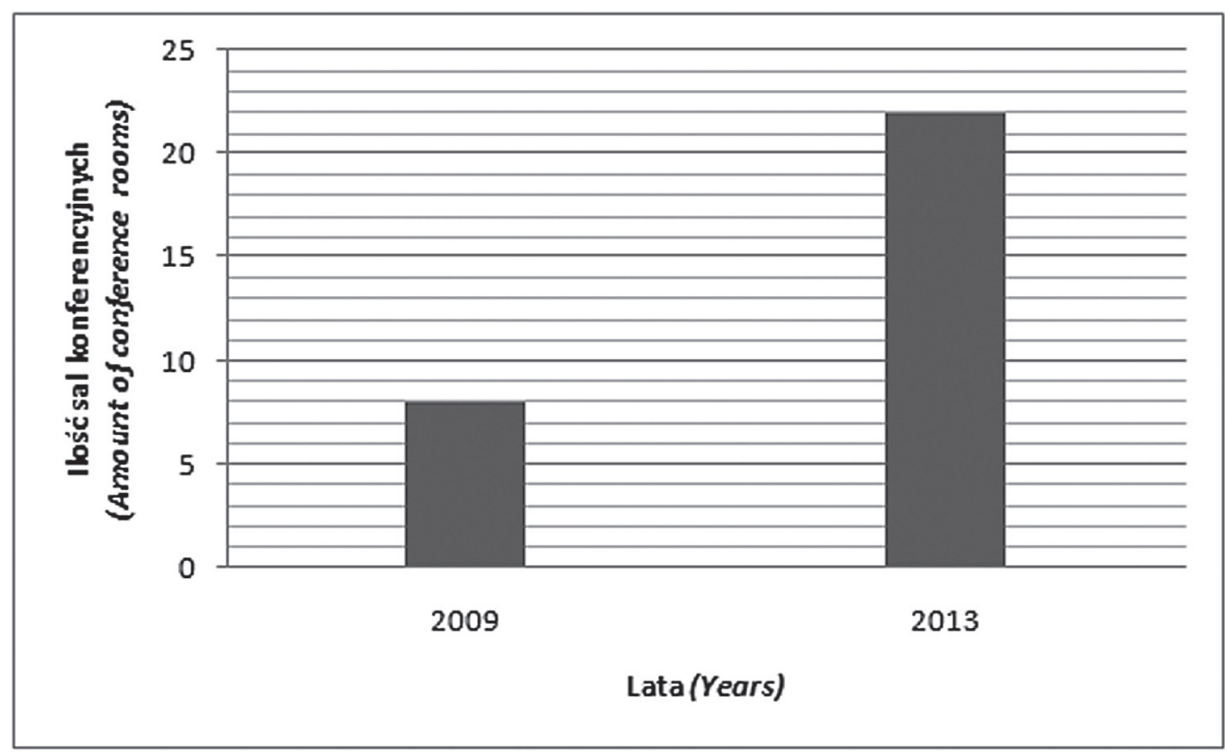

Ryc. 3. Liczba sal konferencyjnych w latach 2009 i 2013 w Białce Tatrzańskiej

Źródło: Opracowanie własne na podstawie Banku Danych Lokalnych

Fig. 3. Amount of conference rooms in 2009 and 2013 in Biatka Tatrzańska

Source: Own elaboration based on Local Data Bank

\section{PERSPEKTYWY}

Mieszkańców Białki Tatrzańskiej cechuje przedsiębiorczość (Hełdak 2015), dlatego też, pomimo już dobrze funkcjonującej infrastruktury turystycznej, planują dalszy rozwój turystyki w swojej miejscowości. Oprócz rozwijania infra- 
struktury narciarskiej, która staje się dominującą formą turystyki w tej wsi, Stowarzyszenie „Czas na Białkę” planuje zorganizowanie ścieżki geoturystyczno-rowerowej wzdłuż koryta Białki. W jej skład mają wejść, oprócz wytyczonej drogi dla rowerów, także tablice informacyjne opisujące budowę geologiczną wybranych punktów na trasie. Ponadto, wstępnie jest też planowane zainstalowanie ławek oraz zadaszonych punktów przystankowych. To kolejny pomysł, którego celem jest przyciągnięcie turystów także w sezonie letnim. Planuje się także poprawę infrastruktury pod kątem turystyki pieszej oraz rowerowej. Wszystkie te pomysły są na razie w fazie projektów, ale doświadczenia efektywności działań mieszkańców Białki Tatrzańskiej z przeszłości pozwalają z optymizmem patrzeć w przyszłość.

\section{PODSUMOWANIE}

Białka Tatrzańska od końca II wojny światowej stopniowo rozwijała usługi turystyczne. Początkowo była to tylko agroturystyka (i to na niewielką skalę) oraz turystyka piesza. Przełomem okazało się wybudowanie pierwszych wyciągów narciarskich w latach 70. XX wieku. Wówczas jednak Białka Tatrzańska pozostawała wciąż w cieniu Zakopanego, a nawet sąsiedniej Bukowiny Tatrzańskiej. Bardzo dynamiczny rozwój turystyki miał miejsce po roku 1989, a zwłaszcza po roku 1995. Wtedy wybudowano największe kompleksy narciarskie. Z czasem narciarstwo zjazdowe stało się wiodącą formą turystyki w tej miejscowości. Do niej zaczęły dołączać inne - turystyka biznesowa (motywacyjna i konferencyjna) oraz turystyka SPA \& Wellness. Można przypuszczać, że w najbliższych latach zapewne nastąpi dalszy rozwój turystyki narciarskiej, a także być może geoturystyki lub turystyki rowerowej (ryc. 4).

W niniejszym opracowaniu, pomimo trudności w zdobyciu wszystkich danych oraz problemów ze sklasyfikowaniem celu przyjazdu turysty (obiekty, w których zatrzymują się turyści nie prowadzą statystyk celu przyjazdu gości, często też turyści łączą cele przyjazdu, tzn. korzystają zarówno z infrastruktury narciarskiej, jak i np. basenów termalnych), starano się w zarysie przedstawić rozwój funkcji turystycznych w omawianej miejscowości. Mimo tych braków wydaje się, że cel został osiągnięty. 


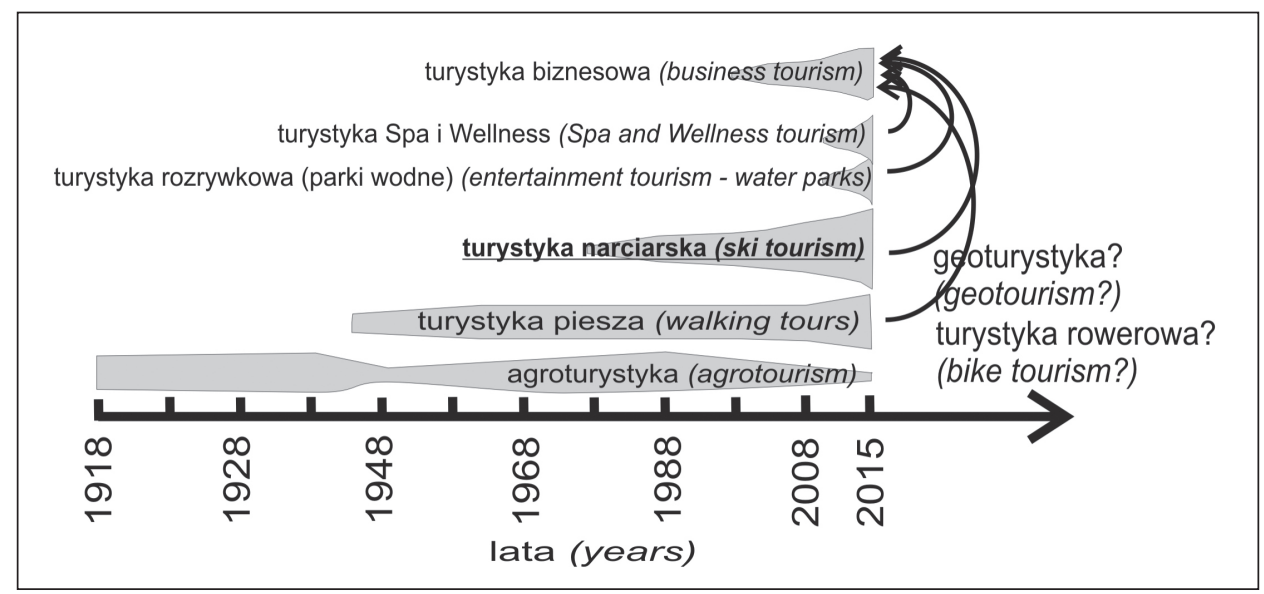

Ryc. 4. Etapy pojawiania się wybranych sektorów turystyki w Białce Tatrzańskiej

Źródło: Opracowanie własne

Fig. 4. Stages of appearance of selected sectors of tourism in Biatka Tatrzańska

Source: Own elaboration

\section{SUMMARY}

Białka Tatrzańska, located in Bukowina Tatrzańska commune (Lesser Poland voivodeship) is a village, which has gradually developed tourist services for over 100 years. Initially, from the interwar period, it was the agrotourism, then, in connection with Polish Tourist and Sightseeing Society activity - walking tours. The real breakthrough was the launch in the 70s of the twentieth century the first ski lift. Since then, the ski tourism has become the dominant service in this place. Suffice to say that currently in this village there are already 9 chairlifts and nearly 20 drag lifts. With the development of skiing there appeared further supplementary services such as SPA \& Wellness tourism and recently business tourism too. This dynamic development of the village would not be possible without favorable geographically conditions and entrepreneurship of local people.

\section{LITERATURA}

Baumgart-Kotarba M., 1983: Ksztaltowanie koryt i teras rzecznych $w$ warunkach zróżnicowanych ruchów tektonicznych (na przykładzie wschodniego Podhala), Prace Geograficzne, 106, 1-119.

Gaworecki W., 2003: Turystyka, Polskie Wydawnictwo Ekonomiczne, Warszawa, 13-104.

Hełdak D., 2014: Założenia i rozwój zachodnich stoków Czarnej Góry (Podhale), praca magisterska, materiał niepublikowany, Uniwersytet Pedagogiczny im. KEN, Kraków, 1-87.

Hełdak D., 2015: Geograficzne uwarunkowania rozwoju wybranych sektorów turystyki w dolinie Białki (Podhale), [w:] A. Dłużewska, G. Iwanicki (red.), Geograficzne i ekonomiczne uwarunkowania rozwoju turystyki, Wyd. Armagraf, Lublin-Krosno, 59-68.

Kaczmarska A., 2014: Wybrane czynniki rozwoju turystyki, [w:] U. Zagóra-Jonszta (red.), Kategorie i teorie ekonomiczne oraz polityka gospodarcza, Studia Ekonomiczne Uniwersytetu Ekonomicznego w Katowicach, Katowice, 176, 201-215.

Kondracki J., 2009: Geografia regionalna Polski, Wyd. Nauk. PWN, Warszawa, 1-444. 
Leszka G., 2013: Podstawy turystyki, Wydawnictwa Szkolne i Pedagogiczne, Warszawa, 22-72.

Mapa topograficzna Polski, arkusz 183.3 Zakopane Pn, 1992, Państwowe Przedsiębiorstwo Geodezyjno-Kartograficzne.

Mastella L., Konon A., Mardal T., 1996: Tektonika fliszu podhalańskiego w dolinie Białki, Przegląd Geologiczny, 12, 1189-1194.

Stasiak A., 2006: Produkt turystyczny - szlak, Turystyka i Hotelarstwo, 10, 9-40.

Uglis J., Jęczmyk A., 2015: Agroturystyka jako faktor zrównoważonego rozwoju, Prace Naukowe Uniwersytetu Ekonomicznego we Wrocławiu, 379, 57-66.

\section{Źródla internetowe}

http://klimat.imgw.pl/wp-content/uploads/2013/01/1_6.pdf [dostęp: 7.01.2016].

http://krakow.rzgw.gov.pl/Program_Bialka/Opracowanie.pdf [dostęp: 25.02.2015].

$\mathrm{http} / / /$ stat.gov.pl/bdl/app/miejsc_w.display?p_id=6153\&p_token=0.20923446514120547 [dostęp: 7.01.2016].

http://www.bialka.tatrzanska.com/obialce/zima.html [dostęp: 30.10.2015].

http://www.czasnabialke.pl/bialka_tatrzanska/historia [dostęp 26.02.2017].

http://www.tatryski.pl// [dostęp: 30.10.2015]. 